Review Article

\title{
Institutional Framework in Flood Management in France and Recommendations for Turkey
}

\section{Fransa'da Taşkın Riski Yönetiminde Kurumsal Çerçeve ve Türkiye İçin Öneriler}

\author{
Işıl SAKIN ${ }^{1}$

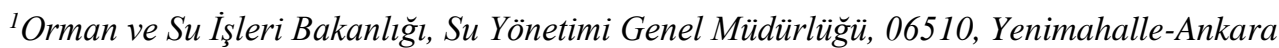 \\ isakin@ormansu.gov.tr
}

Received date: 12.04.2017, Revised date: 07.07.2017 Accepted date: 17.07.2017

\begin{abstract}
The purpose of this study is to; make proposals regarding the authority, duty and responsibility distribution in the Flood Risk Management through the examination of the example from an EU member country and comparison with the existing practices in Turkey in order to provide flood management plans prepared at the basin scale in Turkey with the active participation of all stakeholders and to provide the necessary coordination on flood management at all scales. Within this context, a quick scan study on Member States of the European Union was carried out, legal framework, institutional framework, responsibility distribution and the major institutions involved in flood risk management in France were examined and compared with the implementation in Turkey. By taking the advantage of the information gained from this assessment and taking into consideration the current situation, the proposals were made regarding the duties and responsibilities of the Flood Risk Management Turkey.

Keywords: flood risk management in France, institutional framework of flood risk management, flood risk
\end{abstract} mangement recomendations for Turkey

\section{$\ddot{O} z$}

Bu çalışmanın maksadı, Türkiye'de taşkın yönetim planlarının tüm paydaşların aktif katılımıyla havza ölçeğinde hazırlanması ve taşkın yönetimi ile ilgili gerekli koordinasyonun her ölçekte sağlanabilmesi için; AB üye ülke örneği incelenmesi ve Türkiye'deki mevcut uygulamalarla karşılaştırılması yoluyla Taşkın Riski Yönetiminde yetki, görev ve sorumluluk dağılımı ile ilgili öneriler sunulmasıdır. Bu kapsamda Avrupa Birliği üyesi ülkeler ile ilgili bir hızlı tarama çalışması yapılmış, Fransa'daki taşkın riski yönetiminin yasal çerçevesi, genel çerçevesi, sorumluluk dağılımı ve taşkın riski yönetiminde yer alan başlıca kurumlar incelenerek Türkiye'deki uygulamalar ile karşılaştırılmıştır. Bu değerlendirmeden elde edilen bilgilerden faydalanılarak ve mevcut durum göz önüne alınarak Türkiye'deki Taşkın Riski Yönetiminde yetki, görev ve sorumluluk dağılımı ile ilgili öneriler sunulmuştur.

Anahtar sözcükler: Fransa'da taşkın riski yönetimi, taşkın risk yönetiminde kurumsal çerçeve, taşkın risk yönetimi içinTürkiye'ye öneriler

\section{Introduction}

Flood events are among the most important disasters in the world, and even though they are natural disasters, human activities are the main reason of their effects being so great. Settlements activities in floodplains, interventions in riverbeds, increased urbanization and industrialization activities are some of those activities. In addition to human activities, another reason for the increase in flood risk in recent years is thought to be climate change and an increase in heavy rainfalls through the impact of climate change 
is foreseen. Taking these factors into consideration, it is expected that the floods may increase both in frequency and damage and depending on this, the importance of flood management increases day by day.

Since it is known that damages caused by floods cannot be prevented only by controlling flood control, flood risks must be managed through a multidisciplinary and holistic approach in order to ensure that these damages are reduced or even completely eliminated when possible. In this context, it is necessary to assess the basin as a whole, taking into account the upstream - downstream relationship in the basin and focusing not only to floods, but also to parameters that can affect or can be affected from floods.

In many countries, notably in European countries, the local flood prevention approach has been shifted to "management of flood risks on a wider scale". However, in order to realize this comprehensively, according to the multidisciplinary approach; it is necessary to include many institutions and organizations into the flood risk, which constitutes the important part of the flood risk management, provide them perform their activities in coordination, and in cooperation when necessary, with each other. Moreover, Flood Risk Management Plans should be prepared at basin scale and with the active participation of all stakeholders.

Each institution in Turkey performs their activities regarding Flood Management separately within its field of activity and responsibilities. A flood risk management structure, by which all institutions having activities related to floods can participate in and contribute to the decision making process, will contribute to more effective management of floods, obtain more efficient results, prevent duplication of work and ensure the effective use of resources.

The establishment of the General Directorate of Water Management within the Ministry of Forestry and Water Affairs of Turkey and the studies carried out in this context are considered as important steps taken in this direction. Another important step was the establishment of Basin Management Committees and Provincial Water Management Coordination Boards. Following those steps; it will be beneficial to review and strengthen the existing institutional structure and legal regulations in order to implement the basinscale flood risk management approach more effectively.

Although the legal framework and institutional structure are complementary subjects, the focus of this study is on institutional structure since each one is the subject of a comprehensive study.

Within this context, legislative framework, general framework of flood risk management, responsibility distribution and the main institutions involved in flood risk management in France, which is one of the Member States of the European Union, have been examined.

As a conclusion, suggestions for the strengthening the Flood Risk Management in Turkey have been presented by benefiting from France's experiences. 


\section{Method}

The country to be studied, for the authority-responsibility distribution and cooperation between institutions in flood risk management, has been selected among the Member States of the European Union with the aspect of being an example both for basinscale governance and implementation of Floods Directive.

A quick scan of the current 28 EU member countries was conducted and the information was gathered on the; year of incorporation, population, surface area, number of basins, institutions responsible for the preparation of Flood Management Plans and whether or not the same institutions were responsible for preparation of River Basin Management Plans.

As a result of the assessment, it was decided to examine France since it was the largest country in the EU in terms of area, the second largest country in the EU in terms of population and recently had some administrative transitions from centralized management to decentralization to some extent where some responsibilities transferred to the local authorities.

\section{Results}

\section{General Information}

In France, there are 27 Regions, 5 of which are on overseas, 101 Departments, 36,000 Municipalities and 13 River Basin Regions (RBR), 5 of which are on overseas territories and 8 of which are on mainland. The 8 river basin areas in mainland are managed as 6 main basins. Five of these (Rhône, Adour Garonne, Rhine-Meuse, Artois Picardie, Seine-Normandie) are international basins shared with Belgium, Luxembourg, Germany, Switzerland, Italy, Spain and with some other European countries (European Comission, 2012).

Four of the French River Basin Regions are on the islands (Corsica, La Réunion, Martinique and Guadeloupe). For the Meuse river basin, two separate but connected River Basin Regions (Sambre and Meuse) have been identified. However, these two River Basin Regions are managed together with the Rhine River Basin Region as Meuse and Rhine River Basin (European Comission, 2012) (Sionneau, 2014). 
Table 1. River Basin Regions in France and Shared Countries (European Comission, 2012)

\begin{tabular}{|c|c|c|c|}
\hline $\begin{array}{l}\text { River } \\
\text { Basin } \\
\text { Code }\end{array}$ & Name & $\operatorname{Size}\left(\mathbf{k m}^{2}\right)$ & $\begin{array}{l}\text { RBR Sharing } \\
\text { Countries }\end{array}$ \\
\hline FRA & $\begin{array}{l}\text { Scheldt and Somme, Channel and The North Sea } \\
\text { coastal waters }{ }^{2}\end{array}$ & 18.738 & BE, NL \\
\hline FRB1 & Meuse $^{3}$ & 7.787 & BE, DE, LU, NL \\
\hline FRB2 & Sambre (part of transboundry Meuse basin) ${ }^{3}$ & 1.099 & $\mathrm{BE}$ \\
\hline FRC & Rhine $^{3}$ & 23.653 & $\mathrm{BE}, \mathrm{CH}, \mathrm{DE}, \mathrm{LU}, \mathrm{NL}$ \\
\hline FRD & Rhone and Coastal Mediterranean & 120.427 & $\mathrm{CH}, \mathrm{ES}, \mathrm{IT}$ \\
\hline FRE & Corsica $^{4}$ & 8.713 & - \\
\hline FRF & $\begin{array}{l}\text { Adour, Garonne, Dordogne, Charente and coastal } \\
\text { waters of Aquitania }\end{array}$ & 116.475 & ES \\
\hline FRG & Loire, Brittany and Vendee coastal waters & 156490 & - \\
\hline FRH & Seine and Normandy coastal waters & 93991 & $\mathrm{BE}$ \\
\hline FRI & Guadeloupe $^{4}$ & 1780 & - \\
\hline FRJ & Martinique $^{4}$ & 1102 & - \\
\hline FRK & Guyana (French) $^{4}$ & 90000 & - \\
\hline FRL & Réunion Island ${ }^{4}$ & 2512 & - \\
\hline
\end{tabular}

France has a pyramidal structure due to the centralization of power for a long time. However, since the beginning of the 1980s, the process of "transition to decentralization" has resulted handing the authority to the three levels of local authorities (Region, Department and Local Authority) and the central government has retained the authority regarding some fields such as the risk management, Health Care, Justice or National Security. The transitional movement has assigned many responsibilities, such as economic development, environmental policies and city planning to around 36,000 local governments. These separations of responsibilities have led to considerable difficulties and contradictions for local authorities, and the lack of a concrete co-operation between the government and local authorities have led to disorders (Larrure, Gralepois, \& Trémorin, n.d).

The flood policy was renewed in 1995 with a new legal document called Flood Risk Prevention Plan (Plan de Prévention des Risques d'Inondations - PPRI). Following some dramatic events in the south of France, the central administration intended to reduce urbanization in flood plains including possible flood risk areas, local authorities responsible for planning were restricted for this reason, and PPRI was interpreted as a way to establish control over local authorities and the decision making process for spatial planning (Larrure, Gralepois, \& Trémorin, n.d).

In 2002, an integrated approach at basin scale was promoted by providing public financial support to are provided to the programs called "Flood Prevention Action

\footnotetext{
${ }^{1}$ Information regarding EU Country Codes: http://ec.europa.eu/eurostat/statisticsexplained/index.php/Glossary:Country_codes

${ }^{2}$ Artois Picardie River Basin

${ }^{3}$ Rhine - Meuse River Basin

${ }^{4}$ Overseas Basins
} 
Programs (PAPI), which allows, in order to promote an integrated approach at basin scale ${ }^{5}$. The purpose of these programs is to support an integrated approach to the protection and hazard reduction activities by focusing simultaneously on regulating the flow of the rivers in the upstream, protecting residential areas and reducing the vulnerability (OECD Publications, 2006). The basis of PAPI programmes is to finance the investments to redesign, re-locate or build new flood protection infrastructures that transmit flood runoffs from the areas with high vulnerability (mostly urban areas) to the areas with low vulnerability (such as natural land and agricultural land) in order to reduce total risks at the river basin scale (Enjolras, Erdlenbruch, Grelot, Kast, \& Thoyer).

On August 1st1st 2003, the Advisory Board for the Prevention of Large Scale Natural Risks (Conseil d'orientation pour la prevention des risques naturels majeurs COPRNM) was founded and commissioned under the supervision of the Ministry responsible for ecology and sustainable development to "provide ideas and proposals in the field of prevention of natural risks" (Decree No: 2003-728). Members are composed of all relevant ministries, insurance companies, local authorities, the National Assembly and the Senate (OECD Publications, 2006)

Together with the EU Floods Directive, a new national policy for flood risk management has been developed in France and incorporated into French legislation under the environmental law of 12 July 2010 (Sionneau, 2013)

The Mixed Flood Commission (CMI), which consists of representatives of the state, local authorities and civil society, was established in 2011 to monitor the implementation of the flood risk management policy (MEDDE, n.d)

Under the Law on the national commitment to the environment (LENE) of 12 July 2010, the Commission is responsible for the transposition of the national policy on flood risk management and the EU Floods Directive into the French Law. In its formation, representation of all of the national partners involved in flood risk management (state, politics, authorities, basin public institutions, insurance and non-governmental organizations) is aimed.

CMI has the task of reviewing proposed projects to be defined as "PAPI" or "PSR" (Sudden Flood Plans) and participating in the development of the National Flood Management Strategy (SNGRI) ${ }^{6}$ (AFPCN, 2014)

Formulation of the national policy on flood risk management in France has been initiated as a part of the implementation of the European Union Directive on the

\footnotetext{
5 The basin mentioned here is not the large basins specified within the scope of the Water Framework Directive and the Floods Directive, it is rather the catchment areas that can be defined as the sub-basins of these large basins

${ }^{6}$ The strategy of National Flood Risk Management was determined by the Ministry of Environment Energy and Sea (Risk Prevention Department) with the contribution of the Mixed Flood Commission.
} 
assessment and management of flood risks. For this reason, France has adopted the national strategy for flood risk management (SNGRI) for the first time, which covers short, medium and long terms.

The National Strategy states that everyone has a role related to flood risk and it is necessary for them to harmonize their behaviour with the risk of flooding, involvement of all stakeholders and to have a better understanding of the risks they are exposed to (MEDDE, n.d)

The flood management strategy at the basin level is determined by the Basin Flood Committee according to the basin characteristics, within the framework of the aforementioned national strategy.

In France, legislation including the flood-related articles consists of the following laws:

- Environment Law (Code de l'environnement )

- Strengthening Environmental Protection (renforcement de la protection de l'environnement)

- Urbanism Law (Code de l'urbanisme)

- Regional Units Act (Code General Des Collectivites Territoriales)

- National Environmental Commitment Act (Portant Engagement National Pour l'environnement)

\section{Liability distribution}

In France, the flood policy is implemented at four levels; national, basin, department and municipal levels , (MoFWA, 2012) (Sionneau, 2014)

Main actors in flood management are; The Ministry, regional organization (field services) of the Ministry, basin organizations and local decision makers. In addition, both national and basin level consultation and decision-making bodies have been developed to ensure that the uttermost coordination at national, local and union level is achieved. Their purposes are the development of a common strategy for risk management at the national and river basin level and the implementation of action plans at the basin level.

\section{National level.}

In France, "Risk Prevention Department" of the Ministry of Environment Energy and Sea is responsible for the Flood Risk Management at national level together with transposing and implementing the Floods Directive. Risk Prevention Department determines policies, strategies and standards for the studies undertaken at the regional and local level with the contributions of the Mixed Flood Commission. Regional and local administrations are obliged to organize their work within the framework of these strategies and to act in accordance with the relevant format. The Ministry is also responsible for reporting to the European Union under the Floods Directive (MoFWA, 2012). 
At the national level consultation and decision-making bodies have been developed to ensure coordination in the best possible way. These are Large Scale Natural Risks Prevention Advisory Commission and the Mixed Flood Commission. The Mixed Flood Commission is consisted of the members of the Large Scale Natural Risk Mitigation Commission and the National Water Committee.

Institutional structure of flood preparedness and forecasting system is also carried out under the General Directorate of Risk Prevention under the Ministry of Environment Energy and Sea. In this context, there is a network of hydrometry and flood forecasting which are among the responsibilities of The Central Hydrometeorology and Flood Forecasting Support Service (SCHAPI) at national level. Data obtained from regional flood forecasting units are evaluated at this center and the necessary warnings are made. SCHAPI is also responsible for the management of the national database and the development of new methods and tools.

METEO FRANCE's National Forecasting Center, which is responsible for the meteorological activities, carries out the operation of the numerical weather prediction model and coordinates the output of flood preparedness and forecasting systems. METEO FRANCE is responsible for predictions at synoptic and larger scales and works in coordination with SCHAPI.

Another important element in flood prevention is insurance. The insurance agreements cover not only floods, but also other disasters. Compensation for those who have suffered damage is made by their own insurance companies (MoFWA, 2012)

However, when there is a huge disaster, national solidarity comes into play. The size of the catastrophe is determined by the Mixed Commission. The process starts with the relevant municipality's application to the governor. Subsequently, the governor applies to the Natural Disaster Committee, the Committee transmits its decision to the Government, and the national disaster is declared by the state. When it is declared by the state, the damage from which the citizens are suffered by citizens is covered by their insurance company but it is reimbursed from the Government by the insurance companies (MoFWA, 2012)

The fund used for reimbursement purpose consists of the national pool of funds collected under the CATNAT system (National solidarity system to compensate the victims of natural disasters). While this system covers all disasters, currently $80 \%$ of this insurance is used for floods. This fund is also used for the studies aiming to reduce flood risk and recovery (MoFWA, 2012)

Tasks related to post-disaster works belong to the Ministry of Interior and the Civil Protection Departments and, where necessary, the Army is involved in these activities.

\section{Basin level.}

At the river basin level, there are the River Basin Committees established by the Water Law, which was enacted in 1964. These Committees, also called the water 
parliament, are responsible for directing the water policy at the basin level. These bodies discuss water management issues and analyze the Water Agency's planning documents. The Committee is also responsible for the preparation of the Basin Management Plans under the Water Framework Directive.

While studies on floods were conducted by government agencies at the level of municipalities before PAPI, after PAPI this approach was shifted to the basin level management, which takes hydrographic borders into consideration, not administrative ones. However, the management at the basin level has not been applied at the same level which is currently applied under the Floods Directive as 6 main basins. It was applied at the level of catchment, which can be considered as sub-basins of those main basins.

The current governance on floods in the basin is based on the Basin Committee, Committee, which is defined by the governor of the each basin and includes actors from local public authorities and local authorities responsible for spatial planning and urban planning in the basin,, in accordance with the instructions issued by the Ministry. The Basin Flood Committee is a committee headed by the Basin Governor, and it includes other actors in flood management field in addition to the Basin Committee and contributes to the implementation of the various components of the Floods Directive (Sionneau, 2013) (Sionneau, 2014).

The extent of the Basin Flood Committee is similar to that of the national level. It is a general forum where local actors come together to discuss the basin scale flood risk management policy, the Flash Flood Plans and the Flood Prevention Action Programs. The Basin Flood Committee and other actors in the flood area, including actors involved related to coastal zones and transboundary waters, contribute to the implementation of various components of the Floods Directive (Sionneau, 2013).

The Basin Governor is responsible for the implementation of the Floods Directive at the basin level. Studies at basin scale flood management are carried out by the regional organization of the Ministry of Environment Energy and Sea - DREAL (Regional Directorate of Environment, Planning and Housing), under the Basin Governor. Even though the structuring of DREAL is at the level of the regions, with transition to the basin scale management after the Floods Directive, Coordinator DREAL regional directorates, who will be responsible for the entire basin, have been appointed for each basin (MoFWA, 2012) (Sionneau, 2013) (Sionneau, 2014).

The Regional Director of the Coordinator DREAL fulfils its mission as a basin representative under the control of the Coordinator Governor of the basin, assists the Basin Governor, carries out the secretariat of the Basin Administrative Commission, coordinates the activities of the state units in the water field, advises to the basin organizations and provides technical support (Sionneau, 2013).

DREAL is responsible for all Flood Risk Management Plans and conducts the implementation of Flood Risk Management Plans within the scope of the Directive (MoFWA, 2012). Risk prevention plans prepared within the scope of the Law issued in 
1995 are evaluated at the basin level and used in preparation of flood risk management plans within the scope of the Directive.

The hydrometry network is under the responsibility of six coordinator DREALs at the local level. These units are responsible for the design of measurement networks, strategy development and arrangement of distribution of tools / resources. Flood forecasting services under DREAL determine also the normal level, warning level and crisis level for water levels in rivers.

At the basin level there are also Water Agencies which aim to promote balanced and efficient use of water resources and aquatic environments, water supply, flood control and sustainable development. Water agencies collect and manage data, prepare and submit draft policies, and work on financial requirements. The role of water agencies in flood management is to provide the coordination of different plans and the connection between WFD and FD. It can also provide financing support for flood-related works in some exceptional cases (in the case that the concerning work also have environmental benefits (MoFWA, 2012) (Sionneau, 2014).

\section{Regional level.}

Region; is one of the oldest local governments in France. Legal arrangements in 1982 led to an autonomous structure. The local administrator "Council" is elected once in every 6 years and they elect their own chairman with consensus.

The flood management studies at the regional level are coordinated by DREAL (Regional Directorate of Environment, Planning and Housing) and the regional organization of the Ministry of Environment Energy and Sea (MoFWA, 2012) (Sionneau, 2014).

The Flood Risk Prevention Plans (PPRI), prepared in accordance with the law in 1995, are still in force and are being used in national, regional and local arrangements. However, the plans were revised within the scope of the Floods Directive issued in 2007 and necessary changes were made in line with the requirements of the Floods Directive (MoFWA, 2012) (Sionneau, 2014).

There are regional flood forecasting centers in nineteen out of twenty seven provinces in France. These flood forecasting centers, under DREAL, carry out duties such as hydrometeorological forecasting and monitoring in more than one sub basin, and thus develop knowledge and expertise on floods.

\section{Department and municipal level.}

Departments; are managed by department councils. The councils are elected for 6 years. Department councils elect their own chairman, and chairman have broad responsibilities. They have activities on such as social responsibilities and infrastructure studies. The Department Chairman represents the Government at the Department level. Since the recognition of water as a part of the national heritage, its preservation has gained 
importance in line with common interests and led to the legal increase of the power and influence of the Department Presidents. Each Department has "Crisis forces" that are engaged when necessary for situations e.g. drought and flood. The Department is the main management level in the Government's water resources management and policy. The units of Ministries in Departments are affiliated to the President of the Department.

The municipalities are the smallest local governments in France. City councils are determined by general elections once in every 6 years. In the communes, the administration is composed of a council and a mayor. The City Council and the Mayor are obliged to perform all the necessary investments for the water supply and sewerage services and to collect taxes for the financing thereof (MoFWA, 2012).

Within the framework of the National Flood Management Strategy, Risk Prevention Plans and Action Plans for Flood Protection, Departments and Municipalities, are responsible for;

- Land planning by taking flood risks into consideration,

- Informing citizens about flood risks in the area (e.g. with signs indicating past floods), and

- Crisis Management, mainly under the responsibility of the Mayor, but can also be supported by state powers.

Carrying out flood protection activities is the responsibility of municipalities or municipal associations (unions) (AIDA, 2000).

The evacuation plans are prepared by the Municipalities and the Governor of the Department. When the river exceeds the determined crisis level, evacuation efforts are carried out by the relevant units determined on the plan, under the direction of the municipal police and with the help of the firefighter department (MoFWA, 2012) (Sionneau, Flood Risk Management in France, 2014). Municipalities and/or Departments may come together to form basin-scale authorities, although it is not an obligation.

Department Regional Offices (DDT) of the Ministry of Environment Energy and Sea, perform duties such as contributing to the sustainable development of regions in the planning process, supporting communities in the planning phase of the legislative processes of the land planningplanning, establishing housing and sheltering policy, urban transformation and sustainable development policy, prevention of national and technological hazards and the management of waterways in public access, under the direction of the Department's Governor (MoFWA, 2012).

Flood Risk Prevention Plans (PPRI) was prepared by Department Regional Directorate (DDT - Direction Départementale des Territoires) in accordance with the Law in 1995. Information about past floods, possible future floods, future measures and maps are covered by those plans (MoFWA, 2012) (Sionneau, 2014).

The main objective of Flood Risk Prevention Plans (PPRI) is to ensure that construction is not allowed in the areas with the highest risk, and the floodplain areas are preserved. These plans set out the boundaries of the areas that construction cannot be done 
and the areas where construction can be done under certain conditions, includes urbanization, construction and management rules, and brings specific urban planning arrangements such as construction permit requests (MoFWA, 2012).

PPRI is approved by the governor. As soon as those plans are approved, it becomes compulsory for the Municipalities to comply with. The units in the region are included in the process of preparing the document.

\section{Discussion and Conclusion}

\section{Discussion}

In France, different activities are carried out at the regional, departmental and municipal level as a result of transition from its centralized management in the past to current decentralized management.

Strategies, policies and legislation related to flood management are established at the national level by the Ministry of Environment Energy and Sea (Risk Prevention Department). In addition, different commissions have been formed at the national level to ensure coordination of relevant stakeholders. The decisions of these committees have the characteristic of recommendation for the Ministry. At the basin level, there are structures such as Basin Management Committees, Basin Flood Management Committees and Water Agencies together with DREAL, which is the regional organization of the Ministry, and the activities related to flood risk management are mainly carried out by the Coordinator DREAL determined for each Basin. The aforementioned Basin Flood Committees are the Committees where the active participation of relevant stakeholders is provided and water related issues are discussed at the basin scale. However, except some particular plans, the decisions of the Basin Flood Committees are advisory for the Ministry, which is responsible for approving the plans.

The Flood Prevention Action Plans, called PAPI, were prepared at the level of the hydrographic basins, which can be described as the sub-basins, by the Department Unit of Ministry (DDT). These plans have also formed a basis for the work carried out within the framework of the Floods Directive.

Hereby, it is observed that the planning of the flood management in France is carried out by the organization of the central institution at different levels by ensuring effective participation of all stakeholders at the national, local and basin level, since the main role of the flood risk management is undertaken by the Ministry's organizations at different levels.

Nevertheless, at the point of the implementation of the measures, France does not apply this state-led implementation approach and leaving the implementation of the measures to the departments and municipalities. However, this approach makes it difficult to ensure the standards for structural measures --such as the construction of dikes-,-, maintenance to maintain of these measures and being sure about their protection level, even though the standards are set by the government. 
In France, the studies carried out by various institutes/agencies also have an important place in managing flood risks. The studies such as preparation of maps and inventories, production, storage and distribution of data, development of methodologies and software to be used in the studies such as Flood Risk Assessment, preparation of Flood Hazard and Flood Risk Maps, flood forecasting and early warning system, are being carried out.

In comparison with the implementations in Turkey, the differences are as follows;

- Flood Management Plans are prepared at the basin level in France by the Ministry's basin/regional level organizations and in Turkey at the headquarters of the Ministry for each basin.

- In both countries, there are different plans regarding floods that were prepared in the past, except Flood Risk Management Plans. These plans were prepared at the regional / local level in both the France and Turkey, by field services of Ministry in France and by subsidiary institution in Turkey.

- In France, coordination is provided by commissions at the national level and by the Basin Governor at the basin level. In Turkey, the Ministry and commissions provide coordination at the central level and the Basin Management Committees at the Basin level.

- Flood Control Measures are taken by the municipalities in France. In Turkey, they are taken by the field services of the Ministry's subsidiary institution (DSI) and also the by the municipalities in Metropolitan Cities. The same institutions are responsible for maintenance of these structures in both.

- Land use planning and planning activities are carried out both at central and local level in Turkey and directly at Regional/local level in France.

- In France, while studies on hydrological monitoring and flood forecasting are carried out at the regional level, evaluation and dissemination are carried out at the central level. The necessary meteorological data are obtained from the central Meteorological Administration. Similarly; hydrometeorological monitoring is being carried out by the regional services of two General Directorates of the Ministry in Turkey (DG Meteorology for Meteorological observation and State Hydraulic Works for hydrological monitoring). Evaluation and dissemination are carried out at the central level.

- Flood insurance in France is within the scope of national "natural disaster insurance system - CATNAT -". In Turkey there is no specific insurance for flood disaster hovewer it is covered under different insurance clauses of some insurances such as agricultural insurance, household insurance, etc.

- Training and awareness-raising activities are carried out in France at the regional / local level.

- Ensuring active participation is carried out at basin level in France 


\section{Conclusion}

The approach being implemented in France; flood management planning carried out by the Ministry and the Field Services of Ministry by ensuring the active participation of all stakeholders at the national, basin and local levels; is a very effective system in terms of ensuring that both participation of relevant institutions at all levels and providing the management of flood risks conducted in line with the strategy of central level. From the point of view of Turkey, it is considered that it may be beneficial to support the related unit, which is currently conducting studies from the central level, with a regional organization.

In France, different commissions consisted from relevant stakeholders have been constituted at the national level in order to ensure coordination. As there are similar commissions in Turkey, in, intensification of their activities would support benefiting from them more effectively.

The experience of France on the implementation of the structural measures, transferring responsibility to local stakeholders instead of implementation by the state should be taken into account. It is very important to make sure the level of protection of these structures are ensured, so that it is important to ensure the standards of construction and maintenance of those. In this regard, it would be very beneficial to continue the current approach in Turkey, which is the implementation, operation and maintenance activities for those measures being performed by state institutions which are highly experienced in their field.

In France, flood risk prevention plans determine the boundaries of the areas construction prohibited and the areas that construction is permitted under certain conditions. City planning, construction and management rules for these areas are included in flood risk prevention plans and they bring together special urban planning regulations like construction permission requests. In Turkey, studies for establishing the necessary background for the implementation of such practices -e.g. determination of different building standards according to flood risk level, regulation of legislation related to this issue,-- will provide great benefits in the medium and the long term. 


\section{References}

AFPCN. (2014). Association Française pour la prévention des Catastrophes Naturelles. Commission mixte inondation et SNGRI: retrieved from http://afpcn.org/animation-et-reseau-dacteurs/participationaux-commissions/commission-mixte-inondation-et-sngri/

AIDA. (2000, 09 21). Livre II : Milieux physiques (Partie législative) - AIDA. Accueil - AIDA: retrieved from http://www.ineris.fr/aida/consultation_document/1761

Enjolras, G., Erdlenbruch, K., Grelot, F., Kast, R., \& Thoyer, S. (n.d). Flood management at the basin level in France: Sustainability of local risk-sharing policies. retrieved from http://www.iwra.org/congress/2008/resource/authors/abs612_article.pdf

European Comission. (2012, 11 14). Commission Staff Working Document. European Comission Environment: retrieved from http://ec.europa.eu/environment/water/water-framework/pdf/CWD2012-379_EN-Vol3_FR.pdf

European Comission. Glossary: Country Codes, retrieved from http://ec.europa.eu/eurostat/statisticsexplained/index.php/Glossary:Country_codes

Larrure, C., Gralepois, M., \& Trémorin, J.-B. (n.d). Flood Risk Management Strategies In France's Recent Past: A Story Of Scale And Powers.- STAR FLOOD. STAR FLOOD - Towards More Resilient Flood Risk Governance: retrieved from http://www.starflood.eu/column/flood-risk-managementstrategies-in-frances-recent-past-a-story-of-scale-and-powers/

MEDDE. (n.d). Quelle politique française pour la gestion des inondations? retrieved from http://www.developpement-durable.gouv.fr/Quelle-politique-francaise-de.html

MoFWA. (2012). EU Twinning project on “Capacity Building to Implement Floods Directive” Study Visit Report (17-21.12.2012). TR Ministry of Forestry and Water Affairs, Ankara.

OECD Publications. (2006). OECD Studies in Risk Management - France: Policies for Preventing and Compensation Flood-Related Damage, OECD 2006. retrieved from http://www.oecd.org/france/37397241.pdf

Sionneau, P. (2013). Implementation of Flood Policies in France. retrieved from EU Twinning project on Capacity Building to Implement Floods Directive.

Sionneau, P. (2014). Flood Risk Management in France. (I. SAKIN, Interviewer) 


\section{Extended Turkish Abstract (Genişletilmiş Türkçe Özet)}

Bu çalışmanın maksadı, Türkiye'de taşkın yönetim planlarının tüm paydaşların aktif katılımıyla havza ölçeğinde hazırlanması ve taşkın yönetimi ile ilgili gerekli koordinasyonun her ölçekte sağlanabilmesi için; bir $\mathrm{AB}$ ülkesinin örnek olarak incelenmesi ve Türkiye'deki mevcut uygulamalarla karşılaştırılması yoluyla taşkın riski yönetiminde yetki, görev ve sorumluluk dağılımı konusunda öneriler sunulmasıdır.

Bu kapsamda hem havza düzeyinde yönetime hem de Taşkın Direktifi uygulamalarına örnek oluşturacak bir Avrupa Birliği üyesi ülkesi seçimi için hızlı tarama yapılmış, AB üye ülkeleri arasında yüzölçümü bakımından en büyük, nüfus bakımından ise ikinci büyük ülke olması ve yakın geçmişte merkezi yönetimin bazı sorumluluklarını yerel yönetimlere devrederek yürütülmesine geçiş yapmış olması sebebiyle Fransa'nın incelenmesine karar verilmiştir.

Fransa'da 5'i denizaşırı olmak üzere 27 bölge, 101 departman, 36000 belediye ve 5'i denizaşırı topraklarda 8'i anakarada olmak üzere 13 nehir havzası bölgesi (nhb) bulunmaktadır. Anakarada bulunan 8 nehir havzası bölgesi 6 ana havza olarak yönetilmektedir. Bunlardan 5 tanesi (Rhône, Adour Garonne, RhinMeuse, Artois Picardie, Seine-Normandie) Belçika, Lüksemburg, Almanya, İsviçre, İtalya, İspanya ve diğer Avrupa ülkeleriyle paylaşılan havzalardır.

Fransa'da taşkın politikaları dört seviyede ulusal, havza, departman ve belediye düzeylerinde uygulanmaktadır. Taşkın yönetiminde temel aktörler: bakanlık, bakanlığın bölge teşkilatı, havza organizasyonları ve yerel karar vericilerdir. Bunun dışında ayrıca, ulusal, yerel ve birlik düzeyinde koordinasyonun en iyi şekilde sağlanması için hem ulusal hem de havza bazında danışma ve karar alma organları geliştirilmiştir. Bunların maksadı; ulusal ve nehir havzası düzeylerinde taşkın riski yönetimi için ortak bir stratejinin geliştirilmesi ve havza düzeyinde eylem planlarının uygulanmasıdır.

Fransa'da taşkın yönetimi ile ilgili strateji, politika ve mevzuat ulusal düzeyde Çevre, Enerji ve Deniz Bakanlığı (Risk Önleme Birimi) tarafından oluşturulmaktadır. Bakanlık ayrıca Taşkın Direktifi kapsamında Avrupa Birliğine raporlama görevini de yürütmektedir. Ulusal düzeyde koordinasyonun sağlanabilmesi için ayrıca, ilgili paydaşlardan oluşan farklı komisyonlar mevcuttur. Bu komisyonların kararları Bakanlık için tavsiye niteliği taşımaktadır.

Havza düzeyinde ise havza yönetim heyetleri, havza taşkın yönetim heyetleri ve su ajansları gibi yapılanmalarla beraber Bakanlığın bölge teşkilatı olan DREAL bulunmaktadır. Taşkın riski yönetimi ile ilgili faaliyetler esas olarak her bir havza için belirlenmiş olan koordinatör DREAL tarafindan gerçekleştirilmektedir. Söz konusu Havza (Taşkın) Heyetleri, havza ölçeğinde ilgili paydaşların aktif katılımının sağlandığı ve su ile ilgili konuların görüşüldüğü heyetlerdir. Bununla birlikte havza taşkın heyetlerinin kararları, bazı istisnai planlar haricinde, Bakanlık için tavsiye niteliği taşımakta olup planlar Bakanlık tarafından onaylanmaktadır.

Departman düzeyinde ise, daha ziyade alt havza olarak da nitelendirilebilecek hidrografik havzalar düzeyinde PAPI olarak adlandırılan Taşkın Önleme Eylem Planları Bakanlığın Departman teşkilatı DDT tarafından hazırlanmıştır. Hazırlanmış olan bu planlar, taşkın direktifi çerçevesinde yapılan çalışmalara da altlık oluş̧urmuştur.

Taşkına hazırlıklı olma ve tahmin sistemi Çevre, Enerji ve Deniz Bakanlığına bağlı Risk Önleme Genel Müdürlüğü altında yapılanmışı̧ır. Bu kapsamda oluşturulan hidrometri ve taşkın tahmini ağı ise ulusal düzeyde Merkezi Hidrometeoroloji ve Taşkın Tahmin Destek Servisi SCHAPI'nin sorumluluğundadır. Bölgesel taşkın tahmin birimlerinden gelen veriler bu merkezde değerlendirilmekte ve gerekli uyarılar yapılmaktadır. SCHAPI ayrıca ulusal veri tabanının yönetiminden ve yeni metotlar ile araçların geliştirilmesinden sorumludur. Meteorolojik faaliyetlerden sorumlu METEO FRANCE'in Ulusal Tahmin Merkezi sayısal hava tahmin modelinin işletilmesinden sorumlu olup taşkına hazırlıklı olma ve tahmin 
sisteminin çıktılarının koordinasyonunu sağlamaktadır. METEO FRANCE Sinoptik ölçek ve üzerindeki tahminlerden sorumlu olup SCHAPI ile koordinasyon içerisinde çalışmaktadır.

$\mathrm{Bu}$ şekliyle bakıldığında, her düzeyde taşkın riski yönetimi ile ilgili esas rolün Bakanlığın teşkilatı tarafından üstlenilmesi sebebiyle, Fransa'da taşkın yönetiminin planlanmasının ulusal, yerel ve havza düzeyinde tüm paydaşların etkin katımı sağlanarak merkezi kurumun farklı düzeylerdeki teşkilatı eliyle yürütüldüğü görülmektedir.

Bununla beraber, tedbirlerin uygulanması noktasında Fransa bu devlet eliyle yürütme yaklaşımını uygulamamakta, tedbirlerin uygulanmasını departman ve belediyelere bırakmaktadır. Ancak her ne kadar devlet tarafindan standartları belirlense de, bu yaklaşımın sedde yapımı gibi yapısal tedbirler ve bunların bakımı ilgili olarak bir standardın yakalanmasını ve bu yapıların koruma seviyesinden emin olunmasını zorlaştırdığı ifade edilmektedir.

Taşkın hususunda diğer bir önemli unsur ise sigortadır. Zarara uğrayanların tazminatını kendi sigorta şirketleri karşılamaktadır. Bununla birlikte çok büyük bir afet olduğunda Ulusal Dayanışma devreye girmektedir. Bu şekilde milli afet ilan edildiği durumlarda vatandaşın zararı yine sigorta şirketlerince karşılanmakta ancak, sigorta şirketleri ödemelerini devletten geri almaktadır.

Afet sonrası çalışmalar ise İçişleri Bakanlığı ve sivil savunma birimlerince yürütülmekte, gerekli durumlarda ordu da bu çalışmalara katılmaktadır.

Fransa'da çeşitli enstitüler/ajanslar tarafından taşkın riski ön değerlendirmesi, taşkın tehlike ve taşkın risk haritalarının oluşturulması, taşkın tahmin ve erken uyarı sistemi gibi çalışmalarda kullanılacak metodolojilerin ve yazılımların geliştirilmesi, haritaların ve envanterlerin oluşturulması ve verilerin üretimi, saklanması, dağıtılması gibi çalışmalar yapılmaktadır $\mathrm{Bu}$ çalışmalar taşkın riski yönetiminde önemli bir yere sahiptir.

Türkiye'deki uygulamalar ile karşılaştırıldığında;

- Fransa'da uygulanmakta olan; taşkın yönetimi planlanmasının ulusal, yerel ve havza düzeyinde tüm paydaşların etkin katımı sağlanarak Bakanlık ve Bakanlığın bölge teşkilatı tarafından yürütülmesi yaklaşımı hem tüm düzeylerde ilgili kurumların katılımını hem de taşkın riski yönetiminin merkezi stratejiye uygun yönetilmesini sağlamak açısından oldukça etkin bir sistemdir. Türkiye'de halihazırda bu alandaki çalışmaları merkezi düzeyden yürüten ilgili birimin bölge teşkilatı ile desteklenmesinin faydalı olabileceği değerlendirilmektedir.

- Fransa'da koordinasyonun sağlanabilmesi için ulusal düzeyde ilgili paydaşlardan oluşan farklı komisyonlar oluşturulmuştur. Türkiye'de de benzer komisyonlar olmakla birlikte, bu komisyonların faaliyetlerinin yoğunlaştırılması ile komisyonlardan daha etkin şekilde fayda sağlanabilecektir.

- Fransa'nın özellikle sedde vb. yapısal tedbirler ile ilgili uygulamanın devlet eliyle yapılması yerine sorumluluğun yerel paydaşlara devredilmesi konusundaki tecrübeleri dikkate alınmalıdır. $\mathrm{Bu}$ yapıların koruma seviyesinden emin olunması, dolayısıyla yapımı ve bakımı ile ilgili olarak bir standardın yakalanması oldukça önemlidir. Konusunda oldukça tecrübeli devlet kurumları tarafından bu tedbirlere yönelik uygulama, işletme ve bakım faaliyetlerinin yürütülmesi şeklindeki Türkiye'deki mevcut yaklaşımın devam ettirilmesinin faydalı olacağı değerlendirilmektedir.

- Fransa'da taşkın risk önleme planları ile inşaat yapılamayacak olan bölgelerin ve belli koşullar altında inşaat yapılabilecek olan bölgelerin sınırları belirlenmekte, bu alanlara yönelik şehircilik, inşaat ve yönetim kurallarına yer verilmekte ve bu planlar inşaat izni talebi gibi özel şehircilik düzenlemelerini beraberinde getirmektedir. Türkiye'de de bu tarz uygulamaların yapılabilmesi için gerekli teknik ve yasal altyapının oluşturulmasına yönelik çalışmalar yapılması (taşkın riskinin düzeyine göre farklı yap1 standartlarının belirlenmesi, bu konuya yönelik mevzuat düzenlenmesi vb.) orta ve uzun dönemde büyük faydalar sağlayacaktır.

- Fransa'da ayrıca, çeşitli enstitüler ve ajanslar tarafından taşkın yönetiminin farklı aşamalarında gerekli altlıkların oluşturulması, metodolojilerin ve yazılımların geliştirilmesi gibi oldukça önemli çalışmalar 
yapılmaktadır. Bu tarz çalışmaların çeşitli enstitülerce Türkiye'de gerçekleştirilmesi, kısa vadede sonuçları çok belirgin olmasa da, orta ve uzun vadede ciddi faydalar sağlayacaktır. 